THE HISTORY OF

MISSED OPPORTUNITIES 
This page intentionally left blank 


\title{
THE HISTORY OF
}

\section{MISSED OPPORTUNITIES}

British Romanticism

and the Emergence of the Everyday

\author{
W ILLIAM H. GALPERIN
}


Stanford University Press

Stanford, California

(C) 2017 by the Board of Trustees of the Leland Stanford Junior University. All rights reserved.

No part of this book may be reproduced or transmitted in any form or by any means, electronic or mechanical, including photocopying and recording, or in any information storage or retrieval system without the prior written permission of Stanford University Press.

Printed in the United States of America on acid-free, archival-quality paper

Library of Congress Cataloging-in-Publication Data

Names: Galperin, William H., author.

Title: The history of missed opportunities : British romanticism and the emergence of the everyday / William H. Galperin.

Description: Stanford, California : Stanford University Press, 2017. I

Includes bibliographical references and index.

Identifiers: LCCN 2016052469 (print) I LCCN 2016054147 (ebook) |

ISBN 9781503600195 (cloth : alk. paper) I ISBN 9781503603103 (electronic)

Subjects: LCSH: English literature-18th century-History and criticism. I

Romanticism-Great Britain.

Classification: LCC PR4470 .G35 2017 (print) I LCC PR447o (ebook) ।

DDC 820.9/007-dc23

LC record available at https://lccn.loc.gov/2016052469

Typeset by Bruce Lundquist in 10/15 Minion 
For Tina and in memory of Gabe 
This page intentionally left blank 